\title{
The Huguenot identity in 19th century music: The "Sechs Sprüche zum Kirchenjahr" by Felix Mendelssohn
}

\begin{abstract}
ABSTRAK
Hierdie artikel gaan oor die komponiste Felix Mendelssohn en Giacomo Meyerbeer. Meyerbeer die komponis van die opera Les Huguenots, en Mendelssohn, 'n Jood wat ' $n$ "Calvinis" geword het. Meyerbeer vertel in die opera (1836), geanker aan die Lutherse melodie "'n Vaste Burg is onse God" die verhaal van die Bartolomeusnagmoorde. Mendelssohn, 'n bekeerling tot die sg Hugenote-religie, verwoord sy opregte geloof gedurende die jare 1843-1846 in die voortreflike musikale uitdrukkings Sechs Sprüche zum Kirchenjahr (Ses Spreuke vir die Kerkjaar) wat opgeneem is in die gereformeerde liturgie vir die Brandenburg gemeente. Op 'n bepaalde manier vertel albei komponiste ons iets van die Hugenote-identiteit in die negentiende-eeuse musiek.
\end{abstract}

\section{INTRODUCTION}

Being native Jews, the German composers Giacomo Meyerbeer (1791-1864) and Felix Mendelssohn (1809-1847) show a biographical- and career-run which is different in many ways: whereas Meyerbeer has oriented himself to the world of the theatre, Mendelssohn also devoted his music profession to spiritual, educational and social questions. These effected their respective musical attitude to "Huguenot identity".

Most of Meyerbeer's works are for the opera-scene, and therefore visual. This also is the case with his opera Les Huguenots (The Huguenots) premièred in 1836: aimed at setting into music the tragic history of the French protestants in the 16th century, Meyerbeer attributed a preponderant place to the melody of the German Lutheran choral Ein' feste Burg ${ }^{1}$, this music meant to underline, reinforce and structure what is being seen on stage. The massacre of SaintBarthélemy having been a dreadful moment in the history of the French Huguenots, this choral however couldn't testify to their specific religious sensitivity, or reflect the musical mentality of that time.

Converted to the Calvinism - i.e. the Huguenot religion, Mendelssohn has been searching for the most sincere musical expression of his faith in his Sechs Sprüche zum Kirchenjahr (Six Anthems) composed between 1843 and 1846, allowing these pieces to be inserted in the strict Reformed liturgy of the Brandenburg church.

Is there any possibility to express "Huguenot identity" in music otherwise than by means of recalling melodies of the Huguenot Psalter? ${ }^{2}$ This is what Mendelssohn shows with these his Six

$1 *$ Robert Weeda is a Dutch musicologist, concert manager and choir director, born in 1940 and educated in Brussels. He published on Calvin's Psalter and related items, as well as on a variety of subjects developed in colloquia, seminars and lectures. At present he lives and works in Strassbourg (France).

Mendelssohn also used this choral in his Fifth Symphony "Reformation". Composed in 1829-1830, this symphony was meant to celebrate the tercentenary of the Augsburg-Confession (1530), a text proposing the 28 articles of the Lutheran Declaration of principles worded by Philipp Melanchton and presented to the Imperial Diet in Augsburg en 1530.

2 Following its publication in Geneva (1562), the Psautier huguenot has been translated into German by Ambrosius Lobwasser (1515-1585); published in 1565 with their original melody, the texts enjoyed a new 
Anthems, an internalized and authentic musical setting of biblical texts. ${ }^{3}$

1. First some information is given about the place which the Huguenots acquired in the city of Berlin - from the end of the 17th century until the arrival of the Mendelssohn family in the capital; after this brief outline the article will reflect on the main stages of the composer's life.

\section{THE HUGUENOTS IN BERLIN}

The authorities of many regions of the German Empire worried about the depopulation of the Empire due to the Thirty Years War - 1618-1648. They therefore experienced the coming of the Huguenots as a blessing. Suffering the most from this War, both the regions of Hesse and Brandenburg; they received the refugees with open arms.

At the ecclesiastical level, the German sovereigns permitted the Huguenots to establish their own Churches of the Refuge: they were allowed to build their own temples for the celebration of their worship according to their peculiar liturgy, and in the French language. No permission was however given to introduce their ancient synodal system, being considered as incompatible with the position of the German princes to hold all rights of the Lutheran church-bishops established in their states. Eckart Birnstiel comes to the conclusion in his paper that "I'immigration des quelque quarante mille réfugiés français en Allemagne protestante y aura ainsi définitivement brisé le monopole religieux des idées de Luther et remis en question l'encadrement spirituel exclusif des masses populaires." ${ }^{4}$ (the immigration in protestant Germany of approximately forty thousand French refugees definitely broke down the religious monopoly of Luther's ideas and called in question the exclusive spiritual framing of the popular masses).

At that time, and thanks to both the publicity given to their establishment and their importance, the Land of Brandenburg was having most of the best known institutions in Germany. Being the Kingdom of Prussia since 1701, the princes of this state developed an active policy for the reception of the Huguenots - first the Great Elector Friedrich Wilhelm and, after his death in 1688, his son Friedrich III (Friedrich 1st in 1701).

The privileges granted to the Huguenots by the Potsdam Edict of October 29, 1685 had in fact become effective. In order to be enforced, an official frame named Colonie (Colony) was created; headed by a minister in charge of the Huguenot affairs, its organisational role proved to become vital. Thanks to this institution, the French protestants succeeded in preserving a certain independence. ${ }^{5}$

The most important contingent of French Huguenots, maybe half of all those in Brandenburg,

edition in 1573 with the melodies in a four-voiced harmonisation by Claude Goudimel (1564). Shortly after the 70s, these psalmbooks have found their place in the Reformed church of Germany; see our Itinéraires du Psautier huguenot à la Renaissance, Turnhout, Brepols, 2009, p.171-179.

3 In the frame of an international colloquium devoted to Histoire, mémoire et identités en mutation. Les huguenots en France et en diaspora (XVIe-XXe siècles) and held in October 2010 in Ascona (CH), we delivered a paper on "L'dentité huguenote" mise en musique au XIXe siècle par Meyerbeer et par Mendelssohn"; being mainly centred on Meyerbeer's opera, the original French version of this text will be published in Geneva (Droz) in the bilingual (French/English) proceedings. The present paper pays special attention to Mendelssohn's relation to Huguenot identity.

4 Eckart Birnstiel," La Diaspora Huguenote de la Réforme à la Révolution", in Les Diasporas, Association Culturelle du Razès (A.C.R.), Cahier No. 47. Montréal d'Aude (France), 2009, p.22.

5 In Brandenburg-Prussia, the members of the French colony were called "colonists"; on a juridical level, this designation was not only meant for those definitely established, but also for their descendants born in the Refuge and, eventually, their German spouses. 
established themselves in Berlin, the capital of the state; after the Revocation of the Edict of Nantes (1685), one third of its population of nearly one thousand was of French origin. In spite of the economical dynamism of the Huguenots, they have been mostly outstanding within the non-merchant sector of their new country, in particular in the cultural and scientific domains.

The refugees of the second generation were fluently speaking German as well biblical French - the language of the original family: "ils pouvaient se rendre utiles d'abord dans la vie quotidienne, comme interprètes entre leurs parents et leur environnement social, ensuite sur un niveau beaucoup plus élevé, comme des intermédiaires culturels entre la civilisation française et celle de leur pays d'accueil en devenant journalistes, écrivains, traducteurs. Ils présentaient au public allemand ce qu'il y avait d'idées nouvelles non seulement en France mais aussi dans la République des Lettres. Le mérite de ces hommes de lettre huguenots est avant tout d'avoir ouvert au monde intellectuel de leur pays d'accueil l'accès aux grands débats philosophiques et théologiques, politiques et littéraires qui furent menés au sein de la communauté européenne des intellectuels, par leurs publications et surtout leurs périodiques rédigés toujours en langue française, tel le Journal de Hambourg [et] la Bibliothèque Germanique. "6 (they were able to contribute to the daily life by serving as interpreters between their parents and the social environment and, at a more elevated level, as cultural intermediates between the French civilization and the one of their country of hospitality - becoming journalists, writers and interprets. They offered to the German public all sorts of new ideas belonging not only to France but in general to the République des Lettres. The contribution of these educated Huguenot people is quite clear: through their publications, and especially their periodicals which were always published in French - such as the Journal de Hambourg and the Bibliothèque Germanique - the intellectual world of their new country was given access to the great philosophical, theological, the political and literary debates taking place within the European intellectual community).

Even if, the elite were less in number to reach the German states than other Refuge countries - in particular the Low Countries, "certains penseurs y exercèrent cependant une influence incontestable. Ainsi, l'Académie des Sciences, fondée en 1700 à Berlin par Leibniz, compta parmi ses membres de très nombreux réfugiés ou leurs descendants au cours des décennies suivantes, par exemple Étienne Chauvin, un des savants les plus en vue de son temps."7 (some intellectuals were of undeniable influence. The "Akademie der Wissenschaften" - Royal Academy of Sciences and Letters, originally named Academy of Sciences, which Leibniz founded in Berlin in 1700 - ranks amongst its members quite a number of refugees or their descendants, for example Étienne Chauvin, one of the most prominent scholars of his time). In fact, and not withstanding the original objectives of the Brandenburg authorities, it was in the intellectual and cultural spheres that Huguenots brought their competence to the development of Berlin and the country: during Friedrich II's reign ${ }^{8}$, the French language was dominant at the court of Prussia, and the cultural presence of the refugees is also proven with the "Französisches Komödienhaus" (French

6 Eckart Birnstiel, op. cit., p.27.

7 Julien Léonard (ed.), "La contribution des Huguenots au développement de Berlin et du Brandebourg", in Huguenots. De la Moselle à Berlin, les chemins de l'exil. Metz, Editions Serpenoise, 2006, p.55. In addition to Étienne Chauvin, Jacques Abbadie, Gabriel d'Artis, Philippe Naudé, Isaac de Beausobre, Jean de Barbeyrac, Jean-Louis Formey and Paul Jérémie Bitaubé are to be recalled amongst the many intellectual Huguenot personalities of the Refuge in Germany at that time.

8 Friedrich II of Prussia, known as Friedrich the Great (Friedrich der Große) (1712-1786) is at the same time Friedrich IV of Brandenburg and Friedrich II of Prussia from 1740 till 1786. During his reign, the country joins the great European powers. Although being an enlightened despot, he was tolerant in religious matters. 
Comedy-Theatre) which, after its erection in $1776^{9}$, was elevated to the rank of "Königliches Theater" (Royal Theatre) in 1786 - at the accession of Friedrich Wilhelm II.

\section{Berlin at the arrival of the Mendelssohns}

Being in power from 1797 till 1840, Friedrich Wilhelm III inherited a weakened country. On October 30th, 1809, he suppressed the frame of the "Colony"; consequently, the Huguenots lost their notable advantages and became ordinary citizens of the King - even exemplary patriots of Prussia.

When the Mendelssohns established themselves in Berlin in 1811, the city was neither a harbour like Hamburg, nor a commercial city with fairs such as Leipzig. The city was built out of nothing by the dynasty of the Hohenzollern, but with a significant contribution of the Huguenots.

Founded in 1810 by Wilhelm von Humboldt, the University welcomed the philosophers Fichte, Schelling and $\mathrm{Hegel}^{10}$, as well as the reformed theologian Schleiermacher; famous lectures were also given there by the brothers Schlegel.

Felix Mendelssohn nevertheless escaped from the city at the age of twenty, and felt quite unhappy when he had to work in Berlin from November 1842 till January $1844 .{ }^{11}$

\section{THE MENDELSSOHN DYNASTY}

The ancestor Moses Mendelssohn (1729-1786) was one of the eminent thinkers of the Aufklärung (Enlightenment). This polyglot devoted much of his time to the translation into German of texts from all sources, particularly biblical ones (Psalms, Canticles), conscious as he was of the necessity for his community of faith to have access to the official language of the country.

Felix' father Abraham (1776-1835) was only ten years of age at the death of Moses and he had to battle to get a social position. Working at first as a cashier in a bank in Paris, Abraham left the French capital in 1804 to marry Lea Salomon (1777-1842). They settled in Hamburg where the newly-weds joined his brother Joseph, the banker. Already in 1811 the young couple quit the Nordic city for the capital Berlin where he set up a prospering bank with his brother at the Jägerstrasse 51 .

\section{Felix Mendelssohn: his musical stages}

Born in Hamburg on February 3rd, 1809 where his family was established since two years, the young Felix very soon showed his many gifts. He was astonishing mature, and excelled in everything: handling six modern and old languages, marvellous in drawing and painting, music would notwithstanding take the first place.

With his sister Fanny he undertook his first foreign trip in 1816: in Paris he followed lessons with the French pianist Marie Bigot. Two other journeys to the French capital would follow, in 1825 and again from December 1831 till April 1832.

Starting 1817, Carl Friedrich Zelter (1758-1832) was both Felix and his sisters' master of music, teaching them composition. Felix' teacher for piano would be Ludwig Berger while Carl Wilhelm Henning taught him the violin. In 1800 Zelter took up the headship of the Singakademie which

9 At the Gendarmenmarkt. At that place, a French Church (Dom) was already established in 1688 and erected in 1705; but, after the "Colony" had been suppressed, the Sunday services were held there in German.

10 Mendelssohn is attending in October 1827 Hegel's lectures on aesthetics; given between 1818 and 1829 , these have been published posthumously under the title "Vorlesungen über die Ästhetik".

11 See below, under the heading "Sechs Sprüche zum Kirchenjahr". 
was founded in 1791 by C.F.Rasch. Fanny and Felix would enter this institution on October 1, 1820. The same year Felix composed his first works (Lieder, sonatas for pianoforte, for violin and a trio with pianoforte). In 1824 his started the composing of his (twelve) Symphonies for strings.

"Au décès de sa belle-mère en 1825, Abraham quitte leur maison commune [...] pour la somptueuse résidence du 3 Leipzigerstrasse. Dans le parc, un bâtiment est transformé en salle de spectacle. A compter de cette date, les concerts du dimanche des Mendelssohn, inaugurés trois ans plus tôt, réunissent nombre de mélomanes et notabilités." ${ }^{12}$ (At the death of his mother-inlaw in 1825, Abraham left their common house and moved into in a magnificent residence, at number 3, Leipzigerstrasse. In the park, a building was converted into a concert hall; after that date, the Sunday concerts initiated three years later would welcome quite a number of music lovers and notable people).

At the age of 17, Mendelssohn composed, in 1826, the overture A Midsummer Night's Dream.

In 1829 he undertook his first tour to England: in London the reception was very enthusiastic for Felix the composer, the pianist and the conductor. Mendelssohn would prolong this first trip to Scotland, which would have its musical repercussion in his overture The Hebrides and in the Scottish Symphony. Nine other journeys to this country would follow. In 1831 Mendelssohn made a short visit to Rome. There he met the French composer Hector Berlioz who accepted an invitation to come and conduct his own works in Leipzig in 1843, the city which in the meantime became the musical home of Mendelssohn.

During his third tour in England in 1833, Mendelssohn conducted the first performance of his Italian Symphony. In May of the same year he conducted at the "Niederrheinisches Musikfest" in Düsseldorf; this concert brought him to be elected as "Generalmusikdirektor der Stadt" the following summer. In this city he also started the composing of his oratorio Paulus.

A crucial event in Mendelssohn's career happened in 1835 with his appointment as "Gewandhauskapellmeister" in Leipzig. In 1843, he established the first Conservatory of Germany in this city.

During his ninth tour in England in 1846, the première of his oratorio Eliah was performed in Birmingham.

Shortly after his return from his tenth journey in to England his beloved sister Fanny died on May 14th, 1847. Mendelssohn himself passed away on November 4th of the same year.

2. Bearing the Berlin Huguenot heritage, Mendelssohn converted to the Protestant faith. In this connection, and before starting the study of the Sechs Sprüche, we will make a brief stop on Mendelssohn's double status - that of being a native Jew and a converted Christian.

\section{CONVERSION OF THE MENDELSSOHNS TO THE PROTESTANT FAITH}

\section{Times evolve}

The philosopher J. G. Herder (1744-1803) ${ }^{13}$, expressed the hope that "a day will come that no one will ask in Europe who is Jew and who is Christian; even the Jew will live according the European laws and contribute at his best to the well-being of the State." He was joined in this hope by the father of the Mendelssohn dynasty, Abraham. With the decree of March 11, 1812, the emancipation of the Jews was finally guaranteed, be it with some conditions: Jews had to learn the German language and the conversion to Protestantism was strongly advised. "Les Mendelssohn, surtout Lea - la mère du jeune Felix, tiennent à se comporter en authentiques

12 François-Sappey, op.cit, p.31.

13 Ideen zur Philosophie der Geschichte der Menschheit, 1784-1791. 
citoyens allemands dans un royaume en cours de modernisation. Ils ne pensent pas, ce faisant, renier leurs racines, ils voient dans le christianisme l'universalisation du judaïsme."14 (The Mendelssohns, at first Lea - Felix' young mother, wished to behave as authentic German citizens in a kingdom which was rapidly modernizing. They didn't think they denied their roots by doing so, because they considered Christianity as being the universality of Judaism).

\section{The children's baptism in Berlin}

The archives of the Reformed parish in Leipzig - precisely the one to which Felix Mendelssohn would belong after his marriage to Cécile Jeanrenaud - reveal valuable information on how the Mendelssohns found their way into the Protestant community. Before entering into the core of his subject, Hans-Jürgen Sievers writes ${ }^{15}$ : "In jenen Jahr gab es zahlreiche Übertritte vom jüdischen zum christlichen Glauben. Zu denen, die sich taufen ließen, gehörten auch Kinder und Enkelkinder des Gelehrten Moses Mendelssohn. Der Enkel Felix wurde gemeinsam mit seinen drei Geschwistern am 21. März 1816 von den Prediger der Berliner Jerusalem-Gemeinde Johann Jakob Stegemann im Hause der Eltern getauft." English translation herewith: (In that year many people converted from the Jewish to the Christian faith. Amongst those who were baptised there were also the children and grandchildren of the learned Moses Mendelssohn. On March 21, 1816, his grandson Felix was baptised with his two brothers and sister by pastor Johann Jakob Stegemann of the Berlin Jerusalem-Gemeinde, at the parents' home). On this occasion, Felix received his Christian first names Jakob and Ludwig. ${ }^{16}$

Some years later, at Fanny's confirmation, her father Abraham justified the decision in a letter saying that "we did educate you and your brothers and your sister in the Christian belief because it is the majority's faith; it doesn't contain anything which might move you from the Good, while it holds many things leading to love, to obedience and to tolerance."17

\section{Felix' marriage in Frankfurt}

In 1836 Mendelssohn lead the Cäcilien-Verein choir in Frankfurt: "Dort lernte der junge Musiker die Pfarrerstochter Cécile Jeanrenaud (1817-1853) aus der dortigen Hugenottengemeinde kennen und lieben. Als Felix sie traf, war ihr Vater freilich schon gestorben. Am 8. März 1837 heiraten beide. Sie wurden in der Französisch-reformierten Kirche in Frankfurt getraut. Es wird für sie selbstverständlich gewesen sein, nach ihrem Umzug nach Leipzig sich der dortigen Evangelisch-reformierten Kirche anzuschließen."18 (There the young musician met the daughter of the pastor of the local Huguenot-parish Cécile Jeanrenaud (1817-1853), and fell in love with her; by that time her father had already died. On March 8, 1837 they were married in the Frenchreformed church of Frankfurt. When moving to Leipzig, it seemed normal for them to join the local reformed parish). Now, so to speak, the Mendelssohns definitely entered the Huguenot lineage.

14 Quoted from Brigitte François-Sappey, op. cit., p.21.

15 Hans-Jürgen Sievers, "Die Familie Mendelssohn Bartholdy in den Kirchenbüchern der Evanglischreformierten Kirche zu Leipzig", in In der Mitte der Stadt-Die Evangelisch-reformierte Kirche zu Leipzig von der Einwanderung der Hugenotten bis zur Friedlichen Revolution, edited by Hans-Jürgen Sievers. Leipzig, Evangelische Verlagsanstalt, 2000, p.100.

16 His baptism would allow Felix Mendelssohn to enter the Singakademie in Berlin; it also enabled him to be first nominated in the catholic city Düsseldorf before obtaining the post of "Gewandhauskapellmeister" in the Lutheran bastion Leipzig - a city where he joined the Reformed parish.

17 Quoted and translated from Frans C. Lemaire, Le destin juif et la musique. Trois millle ans d'histoire. Paris, Fayard, 2001, p.295. The author continues by writing that Abraham applied by anticipation the principle which Heinrich Heine was to announce a dozen years later saying that "the certificate of baptism is the entry to the European civilization." (translated from the original French).

18 Hans-Jürgen Sievers, op. cit., p.100. 
The Leipzig parish registers also mention the baptisms of the couple's children, specifying that these events took place in the parents' home, as it was tradition in those times; their fifth and last child - a girl, being baptised in their ultimate residence at Königsstrasse 51 - being Mendelssohn-Haus since the German reunification.

\section{A NATIVE JEW - A CONVERTED CHRISTIAN}

\section{Native Jew}

Baptised in the Reformed church at the age of seven, Mendelssohn presumably never visited a synagogue, except for the commissioned piece from a Hamburg synagogue, the Psalm C"Jauchzet dem herrn alle Welt" for eigth-voices a cappella choir and solo voices. He hardly ever recalled his being the son of Jews, and he was rarely confronted with anti-Semitism - with the notable exception of Richard Wagner in his pamphlet Das Judenthum in der Musik ${ }^{19}$ : written after the première in 1837 of Mendelssohn's Oratorio Paulus, the text emphasizes the composer's work and personality before questioning the place of Jews in the arts.

Richard Wagner cautiously started his writing with much precaution: "Mendelssohn hat uns gezeigt, daß ein Jude von reichster spezifischer Talentfüll sein, die feinste und mannigfaltigste Bildung, das gesteigertste, zartestempfindende Ehrgefühl besitzen kann..." (Mendelssohn has shown us that a Jew may have the amplest store of specific talents, may own the finest and most varied culture, the highest and the most tender sense of honour...).

Then follows the work as such, of which he states the qualities: "Let us here be content with the fact that, in hearing a tone-piece of this composer, we have only been able to feel engrossed where nothing beyond our more or less amusement-craving fantasy was roused through the presentment, stringing-together and entanglement of the most elegant, the smoothest and most polished figures - as in the kaleidoscope's changeful play of form and colour."

When concluding, the tone is no longer one of praise: if not without quality, Mendelssohn's compositions do not hide their insufficiencies - as Wagner writes, "ohne es je ermöglichen zu können, auch nur ein einziges Mal die tiefe, Herz und Seele ergreifende Wirkung auf uns hervorzubringen, welche wir von der Kunst erwarten, weil wir sie dessen fähig wissen, weil wir diese Wirkung zahllos oft empfunden haben, sobald ein Heros unsrer Kunst, so zu sagen, nur den Mund auftat, um zu uns zu sprechen." (without helping him, were it but one single time, to call forth in us that deep, that heart-searching effect which we await from art because we know her capable thereof, because we have felt it many a time and oft, so soon as once a hero of our art has, so to say, but opened his mouth to speak to us.)

According to Wagner, the Jewish artist, by nature, is incapable to reach the profoundnesses of the human heart, an art in which of course Aryan, i.e. German musicians excel.

Wagner concludes his indictment by regretting Mendelssohn's "tragische Zug" (tragic trait) which condemns him in the last resort to "Unfähigkeit" (incapacity) and to "Ohnmacht" (resignation) 20 : "Only where an oppressive feeling of this incapacity seems to master the composer's mood, and drive him to express a soft and mournful resignation, does Mendelssohn have the power to show himself characteristically - characteristic in the subjective sense of a gentle individuality that confesses an impossibility in view of its own powerlessness. This, as we have said, is the tragic trait in Mendelssohn's life-history; and if in the domain of art we are

19 This text was published under the pseudonym K. Freigedank in Neue Zeitschrift für Musik, vol.33, no.9, 3th September 1850; the quotations in English translation are taken from William Ashton Ellis, The Theatre, Richard Wagner's Prose Works, Volume 3. London, Kegan Paul, Trench, Trübner \& Co., Ltd., 19072, p.79-100.

20 Frans C. Lemaire, op. cit., p.221-222. 
to give our sympathy to the sheer personality, we can scarcely deny a large measure of that to Mendelssohn, even though the force of that sympathy be weakened by the reflection that the tragic, in Mendelssohn's situation, hung rather over him than came to actual, sore and cleansing consciousness."

\section{Converted Christian}

On Christmas' Day 1823, Mendelssohn received from his grandmother a copy of J.S. Bach's St Matthew Passion taken from the score belonging to Carl Friedrich Zelter.

The converted Christian is very much aware of the importance of this composition, and he also knows that it has never been heard since the composer's death. This brings Mendelssohn to decide to organize a public performance under his direction. The première would finally take place as a benefit concert in the Singakademie on March 11, 1829; the success was so enormous that a second audition had to be planned - on March 21, Bach's birthday. In his Souvenirs on Felix Mendelssohn and his Letters published in 1872, the actor and amateur singer Eduard Devrient - who sang the role of Christ in that performance - reports how he and Mendelssohn went to see Zelter to use of the choir and the hall of the Singakademie of which he was director of. "Celui-ci ne cacha pas son scepticisme, estimant en particulier que plus personne n'avait encore la patience d'écouter une œuvre aussi longue. Après son accord, [ils] quittèrent leur 'vieil ours' en se félicitant de la chance qu'ils avaient de pouvoir ramener à la lumière une œuvre qui n'avait plus été entendue depuis exactement cent ans."21 (Zelter made no secret of the fact that nobody would have the patience to hear out such a long work. After getting his agreement, they left the "old bear" and were very excited for the opportunity to bring to light a work which has never had been heard since exactly a hundred years).

These documents also reveal that Mendelssohn made quite a number of cuts in the score (twenty three arias and six chorals), modified some ranges, used the pianoforte in the accompaniment of recitatives, replaced the oboe d'amore and oboe da caccia (fallen out of use) by clarinets. All changes probably due to Zelter's comment on the length of the work, brought down to half of its original duration.

Astonishing was that "die sich daraus ergebende Konzentration auf die rezitativischen und chorischen Bibeltexte führte zu einer gegenüber der Originalfassung wesentlich verstärkten Dramatisierung des Werkes."22 (the concentration on the recitative and choral Bibeltexts led to a reinforced dramatic understanding of the piece in comparison with the original). The audience assembled were the elite of those times' in Berlin. Amongst these were present the theologian Friedrich Daniel Schleiermacher, the philosopher Georg Wilhelm Friedrich Hegel and the poet Heinrich Heine ${ }^{23}$. As Fanny Mendelssohn reports, the performance had an enormous effect and changed the hall "in den Anblick einer Kirchen [...] Die tiefste Stille, die feierlichste Andacht herrschte in der Versammlung, man hörte nur einzelne Äußerungen des tief erregten Gefühls." ("into a sort of church. Amongst the audience there was the profoundest silence, the most solemn attention; one could only hear some expression of the excited emotions."); and the critics to write: "Mit tiefem Sinne und ächt religiosen Gefühlen sind die Choräle [...] in den Text des Evangeliums verwebt [...]. Unter den Soli's steht die einfach ausdrucksvolle Declamation der Recitation des erzählenden Evangelisten [...] nächst der würdevollen Behandlung des

21 Frans C. Lemaire, op. cit., p.311.

22 Kurt von Fischer, Die Passion: Musik zwischen Kunst und Kirche. Kassel, Bärenreiter / Stuttgart, J.B.Metzler, 1997, p.113.

23 Quoted from Brigitte François-Sappey, op. cit., p.25: "Avec Heinrich Heine, juif tardivement converti au catholicisme, $[. .$.$] les rapports seront toujours difficiles mais jamais indifférents" (His relations with$ Heinrich Heine, a Jew who belatedly converted to Catholicism, will always be very difficult but never unequal). 
sprechenden Erlösers oben an." 24 ("With a profound sense and real religious feeling the chorals are being woven into the text of the Gospel. Amongst the soli, the Evangelist is declaiming his texts with deep and plain expression, and so does the Redeemer.")

After his Leipzig concerts in Spring 1843, Hector Berlioz finishes a letter to Stephen Heller by proclaiming: "Il n'y a pas d'autre Dieu que Bach, et Mendelssohn est son prophète." 25 ("There is no other God except Bach, and Mendelssohn is his prophet.").

3. Having discovered the diversity of religions, Mendelssohn entered a new creative period in the years 1841/42 which would lead to the composing of the Sechs Sprüche commissioned by Friedrich Wilhelm IV, king of Prussia.

\section{An ecumenical mind}

In 1831, a short journey to Rome - a catholic city per excellence - brought Mendelssohn to meet the French composer Hector Berlioz staying there for study purposes. After their encounter, Berlioz notes in his diary that Mendelssohn "croit fermement à sa religion luthérienne" ("firmly believes in his Lutheran faith"); this is proved in his many Psalms of which most are Lutheran, except Psalm C which is dedicated to a Hamburg synagogue. From 1829, Mendelssohn made ten concert tours in England: for him this country meant a revert to the roots - those of the Renaissance Anglican music (John Taverner, Thomas Tallis, William Byrd, Thomas Morley, Orlando Gibbons etc.) with its generous sound, the expression of profound faith as well as spiritual sense, which would deeply impregnate his own church music, - but also those of Handel's oratorios - in Elijah and Paulus.

In fact, this mixing of the Catholic, Anglican and Protestant worlds he visited perhaps explains part of the choices he made: "tout médium sera bon à cet esprit œcuménique qui pratique depuis sa jeunesse la tolérance comme un art de vivre, sans jamais lâcher son exigence intérieure. Religieux de nature, il peut élever son oraison musicale en allemand ou latin, dans un cadre protestant ou catholique, voire anglican, sans oublier ses origines juives, celles mêmes du monothéisme chrétien." ${ }^{26}$ (any kind of medium will be good for this ecumenical mind who since ever practises tolerance as an art of living, without ever loosing his inner demand. His religious temperament allowed him to express his musical prayer in German or in Latin, in a Protestant or Catholic - or even Anglican - frame, without forgetting about his Jewish origin - the source of the Christian monotheism).

In a similar way he composed in different styles: a cappella in the manner of Palestrina in his immense Te Deum of 1826, the Drei Kirchenmusiken op.23 or the late Motets op.78, where the Evening Service was meant for the Anglican church in London.

Finally, the Sechs Sprüche op.79 and the Deutsche Liturgie were composed for the Domchor in Berlin.

\section{1/42: hinge years}

January 25, 1840 the "Gewandhaus-Kammermusik", a new series of concerts of chamber music started in Leipzig; "beim ersten Kammermusikabend [...] ist auch Mendelssohn dabei, allerdings nur gastweise. Die Hoffnung der Konzertdirektion, ihn an Leipzig zu binden, hat sich nicht erfüllt; Mendelssohn ist inzwischen dem Ruf Friedrich Wilhelms IV. nach Berlin gefolgt. Zuvor wirkte er jede Saison in vier oder gar fünf der sechs Abendunterhaltungen mit. Jetzt aber macht er sich rar; nur noch einmal im Herbst 1843 und viermal im Konzertwinter 1845/46 - da ist er wieder

24 Kurt von Fischer, op.cit., p.113.

25 Hector Berlioz, Mémoires II. Paris, Garnier-Flammarion, 1969, "Lettre à Stephen Heller", p.95.

26 Brigitte François-Sappey, op. cit., p.56-57. 
ganz nach Leipzig zurückgekehrt - musiziert er in einer Kammermusik mit."27 (Mendelssohn was present at the first chamber concert, but as a guest. The management of the Konzertdirektion had wished to bind him to Leipzig, but without success; in the meantime, Mendelssohn has accepted the kings' call to go to Berlin. Before that time he played in four or even five or six evening concerts each season. Now his playing was rare; only once in the Autumn of 1843, and four times during winter season 1845/46 - after that he returned to Leipzig and played chamber music.)

As proof of the above lines about Mendelssohn's playing chamber music in Leipzig, an important change of his career was announced in 1842 when he was about to leave the city, called to Berlin as Kapellmeister of Friedrich Wilhelm IV. At that very moment and for the first time, "Mendelssohn se soumet à une volonté extérieure, celle d'un monarque de la dynastie calviniste des Hohenzollern qui attend de lui une abondante musique cultuelle a cappella pour la cathédrale luthérienne de Berlin, selon les ordonnances rituelles prussiennes de 1829."28 (Mendelssohn submitted himself to an external authority, the monarch of the Hohenzollern calvinist dynasty who expected from the composer much a cappella church music for the Lutheran cathedral in Berlin, in line with the Prussian liturgical order of 1829). On November 22, 1842 the King officially nominated him as director of church music.

Until that time, "Mendelssohn n'avait jamais obéi qu'à sa dévotion personnelle [...]. Dès l'instant où il subit une contrainte, ce tenant de musique absolue se trouve au service d'un texte précis destiné à un moment précis de la liturgie. Le résultat de ces commandes est toujours si parfait qu'on est ému par ces épures polyphoniques." 29 (Mendelssohn was obedient only to his personal devotion. As from that moment he stayed under duress, this champion of absolute music was now the servant of a text destined for a specific moment in the liturgy. The result of these commissions were always so perfect that one is moved by their polyphonic purity). This would be the case with his Sechs Sprüche.

\section{"Sechs Sprüche zum Kirchenjahr"}

From November 1842 till January 1844, Mendelssohn would be the "Generalmusikdirector für kirchliche und geistliche Musik" at the court of the king of Prussia in Berlin. In these years he would compose some works dedicated to the Domchor in Berlin, newly created on May 1st, 1842.

The "Sechs Sprüche zum Kirchenjahr" (Six Anthems for the liturgical year) op.79 are the result of a special commission by King Friedrich Wilhelm IV - who was not Lutheran but reformiert (Reformed) $^{30}$.

Brought together in a collection published in 1850, the Sechs Sprüche were composed for the Domchor between 1843 and 1846 - at a time when Mendelssohn was no longer in office in Berlin. They are a musical setting of verses from the New Testament and the Psalms which were amongst the best loved by the king, and intended for the most important celebrations of the liturgical year (Advent, Christmas, New Year's Day, Passiontide, Good Friday and Ascension Day). Composed for an eight-voice a cappella choir, all six pieces finish with an exuberant "Halleluja!"31; this unique ending is found even in those pieces meant for Passion and Good Friday!

27 Claudius Böhm, Das Gewandhaus-Quartett und die Kammermusik am Leipziger Gewandhaus seit 1808. Altenburg, Verlag Klaus-Jürgen Kamprad (in Zusammenarbeit mit dem Gewandhaus zu Leipzig), 2008, p.50.

28 Brigitte François-Sappey, op. cit., p.138.

29 Brigitte François-Sappey, op. cit., p.179.

30 Did the king know that Mendelssohn was reformed, and member of the Reformed parish in Leipzig ?; cf. also footnote 19 .

31 These "Halleluja!" announce, so to say, those of Igor Stravinsky in his Symphonies of Psalms (1930). 
We should remember that a verse between (the lecture of) the Epistle and the following "Hallelujah!" in those times were one of the rare places of the service in Brandenburg where the very strict liturgy - the "Agende für die evangelische Kirche in den Königlich Preußischen Landen" which Friedrich Wilhelm IV had ordained in 1829 and revised in $1843^{32}$ - nevertheless permitted music going beyond a simple a cappella singing of the congregation. In the Sechs Sprüche, Mendelssohn thus integrated the "Halleluja!" answer in his music.

The Sechs Sprüche form a cycle of short and relatively easy pieces: together they represent one of the rare works which Mendelssohn had truly meant for the Reformed service. As with his Psalms, their phrase is homophone, sometimes slightly relaxed in a polyphonic setting: internalizing the Bible words; they accurately follow the text or the spiritual message of the liturgical feast. Nevertheless, certain passages of the text are proclaimed in a way close to chant singing (on a 'recitative chord') which gives the sound more mystery and profoundness. ${ }^{33}$

\section{Internalizing the words}

The three first pieces - Im Advent, Weihnachten, Am Neujahrstage - adhere very well to the texts, with their tunes based on the chord kept in the tone's color.

Completed on October 5, 1846, Im Advent (Andante) opens in G major, on the joy of "Lasset uns frohlocken" (Let us be joyful); after a solid homophonic section, the second part of the verse offers a very rich polyphony which emerge on a declamatory "Halleluja!".

\begin{tabular}{|c|l|}
\multicolumn{1}{|c|}{ Im Advent } & \multicolumn{1}{c|}{ In Advent } \\
\hline $\begin{array}{c}\text { Lasset uns frohlocken, es nahet der } \\
\text { Heiland, }\end{array}$ & Let us rejoice! The redeemer is coming, \\
\hline den Gott uns verheißen. & whom the Lord has promised. \\
\hline $\begin{array}{c}\text { Der Name des Herrn sei gelobet in } \\
\text { Ewigkeit. }\end{array}$ & The name of the Lord be praised for ever. \\
\hline Halleluja! & Hallelujah! \\
\hline
\end{tabular}

Mendelssohn actually completed Weihnachten on Christmas day (December 15, 1843); this Allegro moderato piece is also in G major. The opening words, "Frohlocket, ihr Völker" (Rejoice, $O$ ye people), are given to the women whereas the men enter at the close of the first line ("und preiset Gott!" - and praise God!). After a few measures, the entire choir comes together rhythmically and textually till "Er hat seine Gerechtigkeit der Welt offenbaret." (He has revealed his justice to the world.), a text it claims two times before being confirmed by several polyphonic and rich "Hallelujas" concluded by a very last and majestic one.

32 In 1822, a "Kirchen-Agende für die Hof-und Domkirche in Berlin" had already been erected; with the versions of 1829/1843, the king had imposed a liturgical union between the Lutherans and the Reformed views.

33 We advise the listening of these Six Anthems on CD by the Kammerchor Stuttgart - conductor Frieder Bernius, and published with Carus (Nr. 83.203). 


\begin{tabular}{|c|l|}
\hline \multicolumn{1}{|c|}{ Weihnachten } & Christmas \\
\hline $\begin{array}{c}\text { Frohlocket, ihr Völcker auf Erden, und } \\
\text { preiset Gott! }\end{array}$ & $\begin{array}{c}\text { Rejoice, ye people of the earth, and praise } \\
\text { God! }\end{array}$ \\
\hline $\begin{array}{c}\text { Der Heiland ist erschienen, den der } \\
\text { Herr verheißen. }\end{array}$ & $\begin{array}{l}\text { The redeemer is come, whom the Lord has } \\
\text { promised. }\end{array}$ \\
\hline $\begin{array}{l}\text { Er hat seine Gerechtigkeit der Welt } \\
\text { offenbaret. }\end{array}$ & He has revealed his justice to the world. \\
\hline Halleluja! & Hallelujah! \\
\hline
\end{tabular}

On the other hand, "Am Neujahrstage" (Andante) is in D minor. Dating from December 25, 1843, it starts calmly with "Herr Gott, du bist unsre Zuflucht für und für" (Lord God, you are our refuge) but increases slowly in strenght, with nevertheless a noble restrain on "von Ewigkeit zu Ewigkeit" (from age to age); "Ehe denn die Berge worden" (from before the mountains were made) is launched two times before the "Halleluja!", first strong on a $f$ and then repeated on a $p$.

This solemn Spruch (Anthem) had its first performance at the ceremonies for New Year's Day 1844 in the Berlin cathedral, together with Mendelssohn's Psalm XCl (verse 11 and 12) "Denn er hat seinen Engeln befohlen über dir" for double choir ${ }^{34}$, equally dedicated to Friedrich Wilhelm IV.

\begin{tabular}{|c|c|}
\hline \multicolumn{1}{|c|}{ Am Neujahrstage } & \multicolumn{1}{c|}{ On New Year's Day } \\
\hline $\begin{array}{l}\text { Herr Gott, du bist uns're Zuhflucht füt } \\
\text { und für. }\end{array}$ & Lord, God, you are our refuge for evermore. \\
\hline Ehe den die Berge worden, & You are our God from age to age, \\
\hline $\begin{array}{c}\text { und die Erde und die Welt er } \\
\text { erschaffen worden, }\end{array}$ & from before the mountains were made, \\
\hline bist du Gott von Ewigkeit zu Ewigkeit. & and the lands and the world were created. \\
\hline Halleluja! & Hallelujah! \\
\hline
\end{tabular}

Both In der Passionszeit and Am Charfreitage are in minor tone

Mendelssohn completed the short In der Passionszeit on February 14, 1844. Three or four solo voices alternate in slow tempo (Adagio) with tutti passages; the choir starts the prayer on a $p$ which brings out some essential terms - "und erbarme dich unseres Elends" (and have mercy on us in our affliction) and "erlöse uns und vergib uns unsere Sünden" (redeem us and pardon our sins), and it concludes with a quite impressive polyphonic building of "Halleluja!".

\begin{tabular}{|l|c|}
\hline \multicolumn{1}{|c|}{ In der Passionszeit } & At Passiontide \\
\hline $\begin{array}{l}\text { Herr, gedenke nicht unsrer } \\
\text { Überthaten. }\end{array}$ & Lord, remember not our wrongdoings, \\
\hline
\end{tabular}

34 In 1846 Mendelssohn will orchestrate and include this piece in his oratorio Eliah (at Nr.7). 


\begin{tabular}{|c|l|}
\hline und erbarme dich unseresElends. & and have mercy on us in our affliction. \\
\hline $\begin{array}{c}\text { Herr, der du unser Heiland bist, stehe } \\
\text { unsei, }\end{array}$ & Lord, who are our saviour, help us, \\
\hline $\begin{array}{c}\text { erlöse uns und vergib uns unsere } \\
\text { Sünden }\end{array}$ & redeem us and pardon our sins, \\
\hline $\begin{array}{c}\text { um der Herrlichkeit deines Namens } \\
\text { willen. }\end{array}$ & for the sake of your glorious name. \\
\hline Halleluja! & Hallelujah! \\
\hline
\end{tabular}

The choir opens the short Am Charfreitage with "Um uns'rer Sünden" (For our sins) in a simple and slow psalmodic declamation, intensively growing towards "Tode am Kreuze" (to death on the cross) culminating in a $f$ accent on "darum hat Gott inn erhöret" (Therefore God has raised him up) of which the Sostenuto e grave is maintained on the first "Halleluja!" expressing the suffering and - maybe - the 'revolt'; in a sudden final $p$, the second "Halleluja!" carries both emotion and confidence of the resurrection which is to happen on Easter.

Finished on February 14, 1844, this Anthem is consistently homophonic and ends in E minor, symbol of Christ's sacrifice.

\begin{tabular}{|c|c|}
\hline Am Karfreitage & On Good Friday \\
\hline $\begin{array}{c}\text { Um uns'rer Sünden willen hat sich } \\
\text { Christus erniedrigt }\end{array}$ & $\begin{array}{c}\text { For the sake of our sins, Christ has made } \\
\text { himself humble }\end{array}$ \\
\hline $\begin{array}{c}\text { und ist gehorsam geworden bis zum } \\
\text { Tode am Kreuze; }\end{array}$ & $\begin{array}{c}\text { and has submitted even unto death on the } \\
\text { cross. }\end{array}$ \\
\hline $\begin{array}{c}\text { darum hat Gott ihm erhöhet, und ihm } \\
\text { einen Namen gegeben, }\end{array}$ & $\begin{array}{c}\text { Therefore God has raised him up, and given } \\
\text { him a name, }\end{array}$ \\
\hline Halleluja! & Hallelujah! \\
\hline
\end{tabular}

The cycle comes to an end with the festive and majestic Am Himmelfahrtstage - the feast of the Ascension of Jesus to heaven - (Allegro maestoso e moderato, in B flat major), a piece which Mendelssohn finished in Leipzig on October 9, 1846. It moves in an alternate movement between homophonic parts (the tenors alone striking up "Erhaben, o Herr, über alles Lob" O Lord, above all praise) and polyphonic parts (with a marvellous entry of the altos!), these reminds of Handel's composing style - an English influence! - in the numerous passages of imitation.

\begin{tabular}{|c|c|}
\hline \multicolumn{1}{|c|}{ Am Himmelfahrtstage } & On Ascension Day \\
\hline $\begin{array}{c}\text { Erhaben, O Herr, über alles Lob, über } \\
\text { alle Herrlichkeit, }\end{array}$ & $\begin{array}{c}\text { O Lord, you rule sublime for all eternity, } \\
\text { above all }\end{array}$ \\
\hline
\end{tabular}




\begin{tabular}{|c|l|}
\hline $\begin{array}{c}\text { herrschest du von Ewigkeit zu } \\
\text { Ewigkeit. }\end{array}$ & praise and majesty. \\
\hline Halleluja! & Hallelujah! \\
\hline
\end{tabular}

\section{TRIBUTES BY ROBERT SCHUMANN}

With his Sechs Sprüche, Mendelssohn has given a true testimony to what Robert Schumann had already written about him in 1835: "Mendelssohn ist ein herrlicher, - ein Diamant direkt vom Himmel; wir haben uns gern, glaub' ich." ("Mendelssohn is a superb man, - a diamond fallen from heaven; I feel we love each other quite well."), saying that he is the most cultivated nature of our time. ${ }^{35}$ However, after the first performance in Leipzig of the Oratorio Paulus ${ }^{36}$, Schumann's compliments were a bit ambivalent. He praised Paulus as: "ein Kunstwerk als reine ein Werk des Friedens und der Liebe. " ("a piece of the most pure art, a piece with peace and love") 37 , but at the same time this praise formed the introduction for severe critique on Meyerbeer's opera Les Huguenots that had it's premiere in Leipzig on 10 April 1837.

At Mendelssohn's death on November 4, 1847 Robert Schuman wrote in his diary, and under a big black cross with his own hand: "Sein Todesanlitz. Wie ein Hierophant sah er [aus], wie ein Gottesstreiter, der überwunden" ("His body. He was looking like a 'Hierophant', as a Godfighter who was defeated."), and adds: "Seine Sendung war erfüllt. Dies wusste er am besten. 'Herr, nun lass deinen Diener in Frieden fahren!' Wie schmerzlich." ${ }^{38}$ ("His mission was accomplished. And this he knew at best. 'Lord, now let your servant go in peace.' How painful.")

\section{BIBLIOGRAPHY}

William Ashton Ellis, The Theatre, Richard Wagner's Prose Works, Volume 3. London, Kegan Paul, Trench, Trübner \& Co., Ltd., 19072

Hector Berlioz, Mémoires II. Paris, Garnier-Flammarion, 1969

Eckart Birnstiel, "La Diaspora Huguenote de la Réforme à la Révolution", in Les Diasporas, Association

Culturelle du Razès, Cahier No. 47. Montréal d'Aude (F), 2009

Claudius Böhm, Das Gewandhaus-Quartett und die Kammermusik am Leipziger Gewandhaus seit 1808. Altenburg, Verlag Klaus-Jürgen Kamprad (in Zusammenarbeit mit dem Gewandhaus zu Leipzig), 2008

Kurt von Fischer, Die Passion: Musik zwischen Kunst und Kirche. Kassel, Bärenreiter / Stuttgart, J.B.Metzler, 1997

35 Letter written in September 1835 to the singer and music critic Gustav Nauenberg.

36 At the Paulinerkirche (the University church), on March 16, 1837.

37 Neue Zeitschrift für Musik, 5th September 1837; cf. also footnote 20.

38 Quoted from Kerstin Sieblist, "Wir haben uns gern, glaub' ich", GewandhausMagazin, Nr. 66. Leipzig, Frühjahr 2010, p.17. The author concludes her article by reminding that "Robert Schumann gehörte zu den sechs engen Freunden, die beim großen Trauerzug von der Wohnung Mendelssohns zur Totenfeier in der Paulinerkirche dem Sarg das Eherngeleit gaben und die Enden des Bahrtuchs trugen." (Robert Schumann was amongst the six close friends who, in the great mourningprocession from Mendelssohns' house to the service in the Paulinerkirche, carried the coffin). Hans-Jürgen Sievers (op. cit., p.102) is adding to this point: "Eine Zusammenstellung der Lebensdaten von Mitgliedern der Gemeinde vermeldet daß Mendelssohn"am 7. November abends 9 Uhr 30 Minuten nach Berlin mit einem Extrazuge abgefürht worden [ist]."Vorher hatte sein Gemeindepfarrer Samuel Rudolf Howard bei einer Gedenkfeier in der Universitätskirche die Traueransprache gehalten."(A collection of biographical data of members of the church says that Mendelssohn"on November 6 at $9.30 \mathrm{pm}$ has been transported by special train to Berlin."Before this, the local pastor Samuel Rudolf Howard had delivered the funeral speech in the University church). 
Brigitte François-Sappey, Felix Mendelssohn. Paris, Fayard, 2003

Frans C. Lemaire, Le destin juif et la musique. Trois millle ans d'histoire. Paris, Fayard, 2001

Julien Léonard (ed), "La contribution des Huguenots au développement de Berlin et du Brandebourg", in Huguenots. De la Moselle à Berlin, les chemins de l'exil. Metz (F), Editions Serpenoise, 2006

Robert Schumann, "Fragmente aus Leipzig", Neue Zeitschrift für Musik, 5th September, 1837

Kerstin Sieblist, "Wir haben uns gern, glaub' ich ", GewandhausMagazin, Nr. 66. Leipzig, Frühjahr 2010

Hans-Jürgen Sievers, "Die Familie Mendelssohn Bartholdy in den Kirchenbüchern der Evanglischreformierten Kirche zu Leipzig", in In der Mitte der Stadt - Die Evangelisch-reformierte Kirche zu Leipzig von der Einwanderung der Hugenotten bis zur Friedlichen Revolution, hrsg. von Hans-Jürgen Sievers. Leipzig, Evangelische Verlagsanstalt, 2000

Richard Wagner (under the pseudonym K. Freigedank), "Das Judenthum in der Musik", Neue Zeitschrift für Musik, 3th September, 1850

Robert Weeda, Itinéraires du Psautier huguenot à la Renaissance. Turnhout (B), Brepols, 2009.

\section{KEY WORDS}

ninenteenth century

Huguenot identity

Meyerbeer, Giacomo

Mendelssohn, Felix

Brandenburg

\section{TREFWOORDE}

Negentiende eeu

Hugenote-identiteit

Meyerbeer, Giacomo

Mendelssohn, Felix

Brandenburg 